\title{
Immigrants in the U.S. Economy: A Host-Country Perspective
}

\author{
Pia M. Orrenius, Ph.D. \\ Federal Reserve Bank of Dallas • Dallas, TX \\ Michael Nicholson \\ Federal Reserve Bank of Dallas • Dallas, TX
}

\section{Introduction}

The contributions of immigrants are many, particularly when it comes to the pace of economic growth.' Immigrants both power and grease the engines that run the economy. In fact, just over half of the increase in the U.S. labor force over the last decade was the result of immigration - legal and illegal. ${ }^{2}$ Immigrants' labor force contributions will continue to be important in the near future as the U.S. workforce ages and the baby boomers retire. Immigration also plays a key role in the business cycle. Immigration is pro-cyclical, meaning foreigners come in greater numbers when U.S. job growth accelerates and in fewer numbers when it wanes. In a similar vein, immigrants help resolve bottlenecks and shortages that arise in growing regions and sectors by moving to areas and industries experiencing high labor demand.

Despite immigrants' contributions to economic growth and efficiency, policymakers will continue to debate the costs and benefits of immigration because, while economic growth makes the economy bigger, a larger economy does not necessarily nake U.S. natives better off. For example, the economic benefits of low-skilled immigration for U.S. natives are offset to a certain extent by the adverse fiscal impact that an increased number of poor households have on taxpayers. Globally, the reallocation of workers from low- to high-income countries still has huge benefits but, because most of these benefits accrue to the migrants, the effect on host-country natives is far less positive. In this way, the perspective from which immigration is viewed makes all the difference to the conclusions of the analysis. Worker migration that is globally optimal and beneficial to the origin country may have negative implications for the host country in certain cases.

\section{U.S. immigrants: How many?}

The foreign-born population reached a 20th century low point in 1970. Since then, the U.S. has witnessed over three decades of mass immigration with large effects on economic growth. Between 1970 and 2007, the foreign-born population 
rose from 9.6 to 38.1 million and, as a share of the population, immigrants increased from 4.7 percent in 1970 to 12.6 percent in 2007 (Chart 1).

\section{Chart 1}

\section{Foreign-born Share of Population Near Historic Peaks}

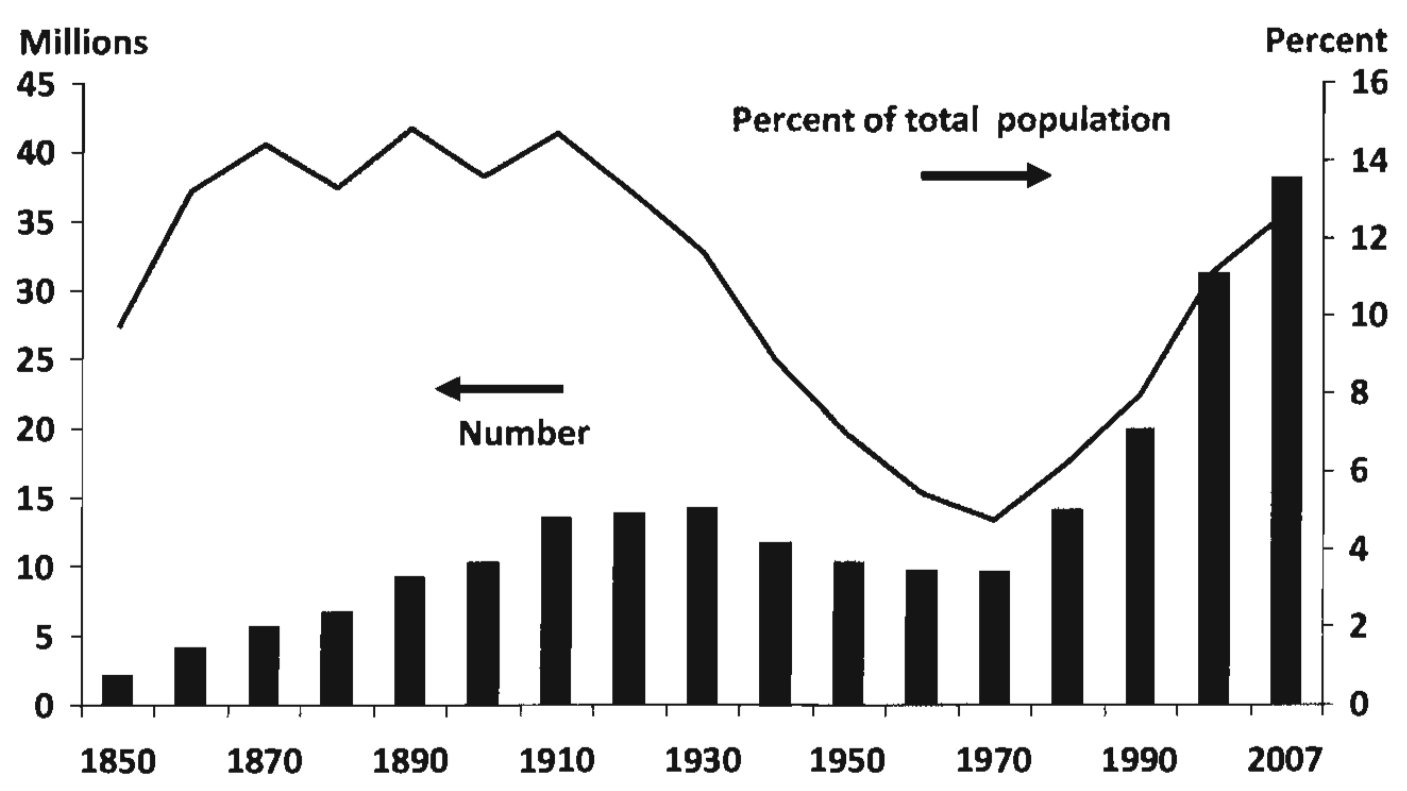

Source: Census Bureau

By 2007, immigrants made up 15.6 percent of the U.S. labor force. ${ }^{3}$ Over the last decade or so, foreign-born workers have contributed roughly half of annual labor force growth. Natives have had a shrinking role in labor force growth due to many factors, notably their declining labor force participation rates. As the nativeborn population ages and the baby boomers retire over the next twenty years, the foreign-born contribution to labor force growth is expected to stay high or even increase. The retirement of baby boomers is expected to result in 80 million workers leaving the U.S. workforce over the next two decades (Social Security Administration, 2007).

The influx of workers on the high and low ends of the skill distribution has made the growth and evolution of certain industries and occupations increasingly dependent on foreign-born professionals and laborers. Immigrants' contribution to job growth is highest in sectors such as construction and extraction that require little formal education. The foreign-born made up about 64 percent of job growth in this sector between 2003 and 2007 (Chart 2). 


\section{Chart 2}

Foreign-born Share of Employment Growth by Selected Occupations

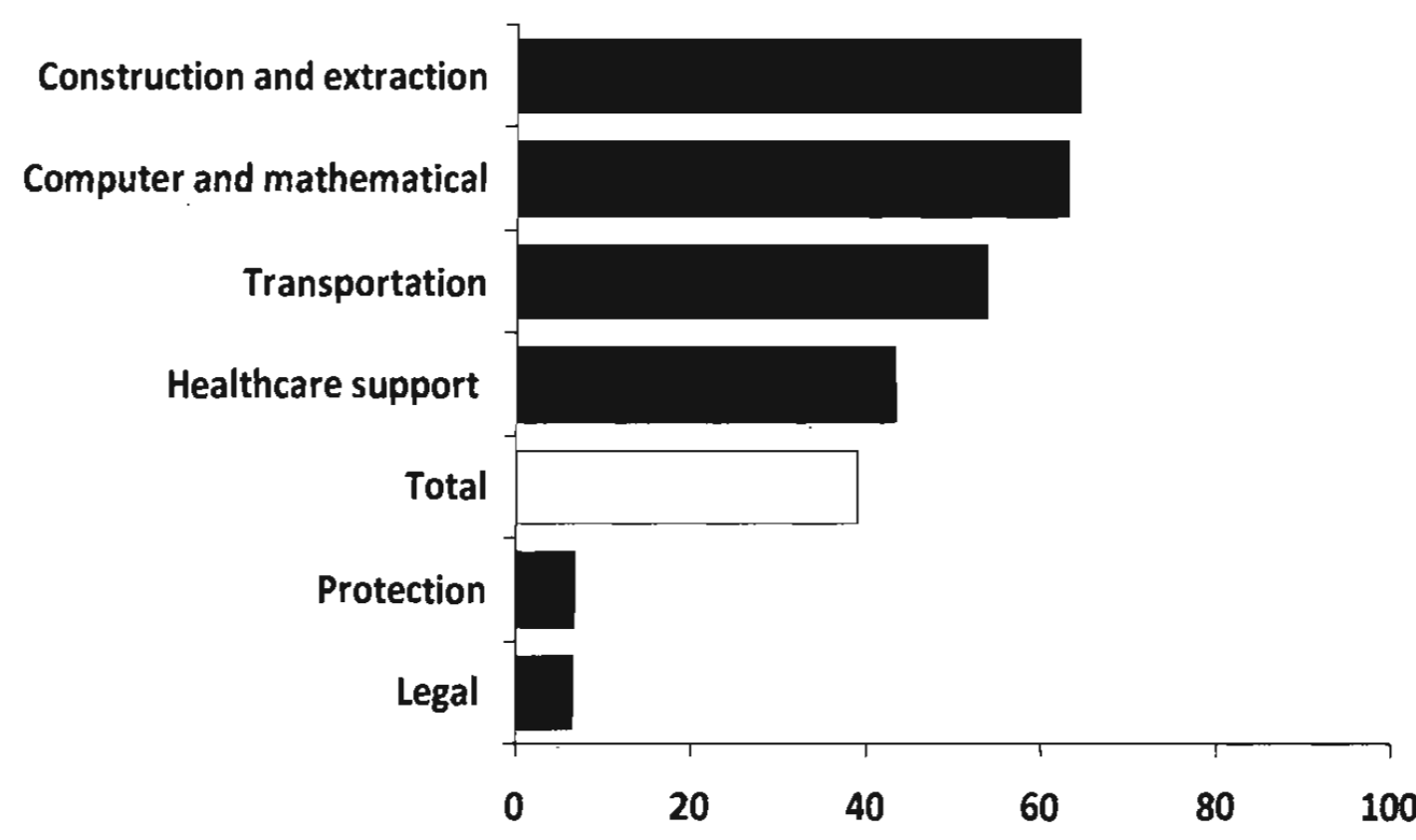

Source: Bureau of Labor Statistics; authors' calculations.

Percent

Note: Change over the period 2003-2007.

Immigrants also made up a large share of job growth in many high-skilled occupations; they were responsible for 63 percent of job growth in computer- and mathrelated occupations between 2003 and 2007. Bear in mind that although foreign workers make up high shares of net job growth in an occupation or industry this does not imply that U.S.-born workers are not in those professions. Natives may be the majority of workers in an occupation, but because they are exiting at a high rate relative to the rate at which they are entering, they make a small contribution to net growth. This is the case in many math, science and engineering fields. Low entry rates are in part due to talented American students who pursue professional degrees rather than graduate school given the shorter education and faster rate of real wage increases in business and law occupations relative to jobs in science, engineering and math (Freeman, 2005).

Immigrants are also important drivers of growth in many other occupations. In healthcare support, for example, which includes nursing, about 43 percent of growth was due to the influx of the foreign-born during this period. Overall, during 2003-2007, the foreign-born made up 39 percent of total employment growth. Occupations with below-average immigrant participation often require U.S. citizenship (e.g., jobs in law enforcement or other protective services) or present substantial institutional and language barriers (e.g., legal professions). 


\section{U.S. immigration: How has it changed?}

During the last forty years or so, changes in immigrant characteristics and immigration policy have accompanied the dramatic rise in immigration. Two changes stand out both with regard to their effects on immigration dynamics and their implications for ongoing policy debates. First, the education distribution of foreignborn workers has become increasingly bimodal and, second, illegal immigration has grown so quickly that it overtook legal immigration for several years.

As mentioned above, immigrants have played an important role in the growth of both high and low-skilled occupations. This is largely because they are disproportionately represented on the extremes of the education distribution (Chart 3). Between 1980 and 2004, the share of foreign-born among workers who lack a high school degree tripled, rising from 10.5 to 32 percent. At the same time, the share of foreign-born among workers who have a Masters or Professional degree doubled (from 7.5 to 15.5 percent) and the share with a Doctorate increased 13.5 percentage points (from 14.5 to 28 percent).

\section{Chart 3}

Share of Foreign-born by Education Level of Workers

\section{Percent}

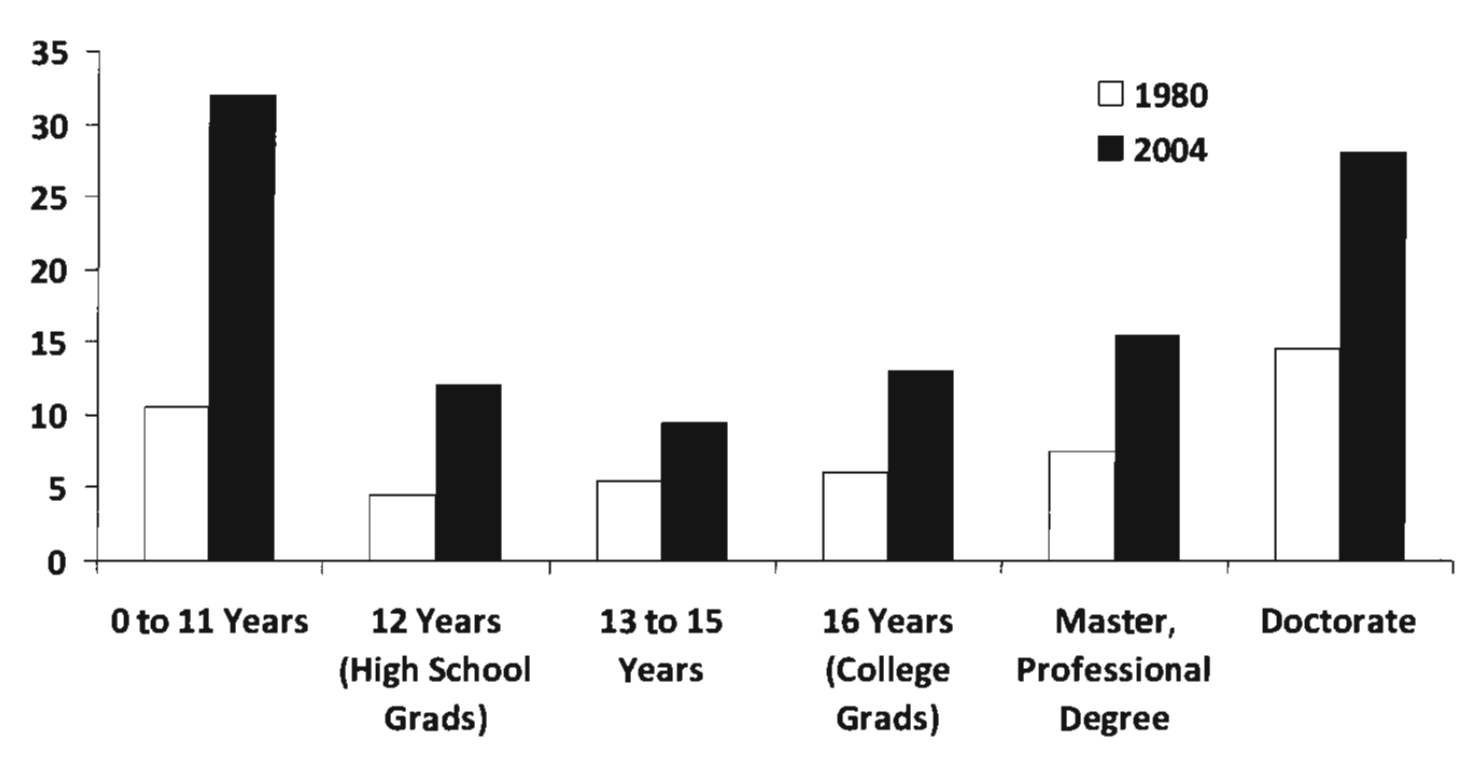

Source: Gianmarco Ottaviano and Giovanni Peri (2006).

Where do native-born workers fall in the educational distribution? They are overwhelmingly concentrated in the middle of the distribution - the average education among U.S.-born workers age 25 and over is about 13 years. Only 5.2 percent 
lack a high school degree and 35 percent have a Bachelors degree or higher. In other words, since labor demand for foreign workers is likely highest where native workers are scarce, it makes sense that foreign-born workers tend to have either very low or very high levels of education.

The second important change with regard to U.S. immigration over the last few decades is the rise of illegal immigration. Jeffrey Passel of the Pew Hispanic Center has developed estimates of the yearly net flow of legal and illegal immigrants into the U.S. since 1990 (Chart 4) (Passel \& Suro, 2005; Passel \& Cohn, 2008). The graphic is striking in that undocumented flows (grey) rivaled legal flows (black) from 1990 to 2004. On average over this period, net undocumented immigrant inflows numbered 518,000 annually as compared with legal immigrants (green card recipients) who numbered 608,000 . Illegal inflows dropped to an average of 275,000 from 2005 to 2008 due to slowing economic growth in the U.S. As a result of many years of large undocumented worker inflows, 30 percent of the 2008 foreign-born population was thought to be made up of undocumented immigrants (about 11.9 million people) (Passel \& Cohn, 2008).

\section{Chart 4}

\section{Volume of Illegal Inflows Rivals Legal}

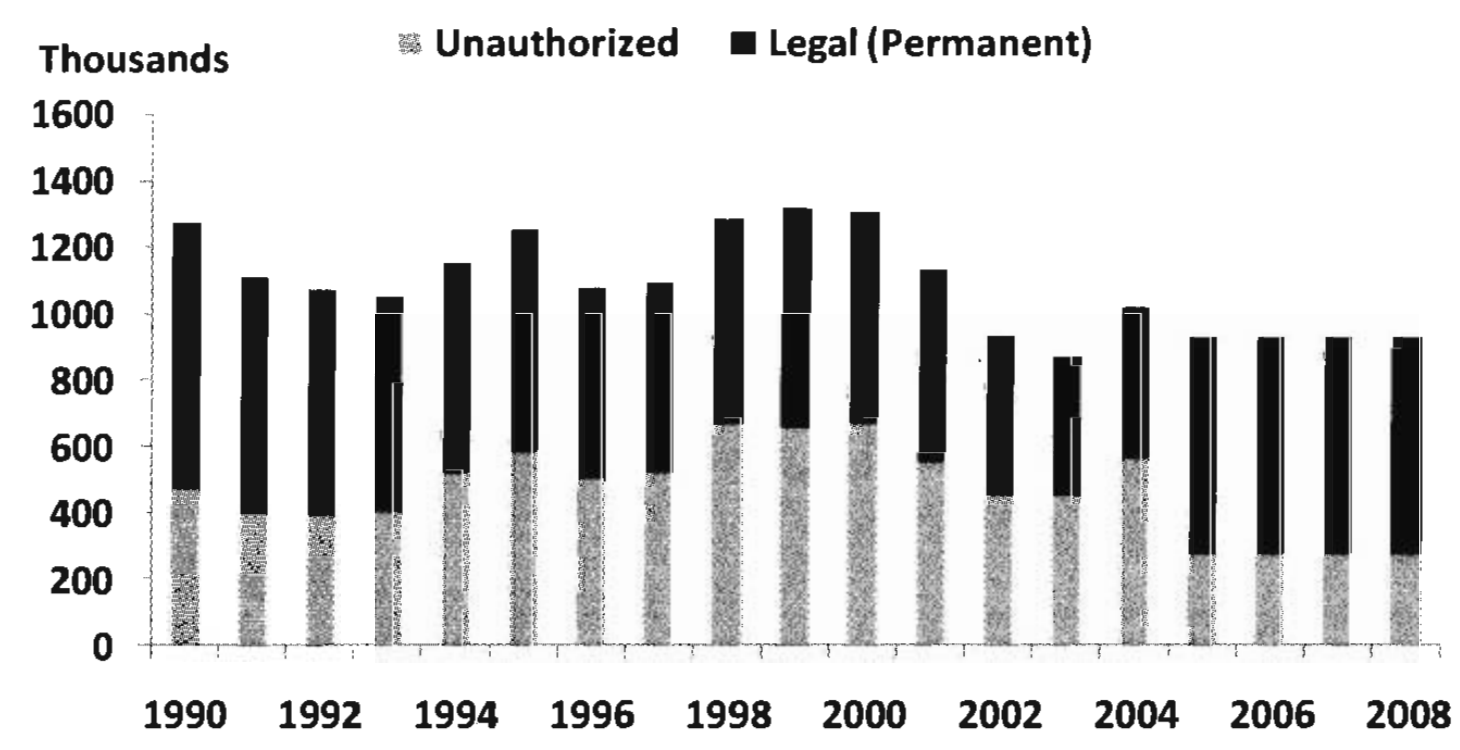

Source: Jeffrey Passel \& Robert Suro (2005); Jeffrey Passel \& D'Vera Cohn (2008).

Note: 1990-2004 annual data from Passel \& Suro; 2005-2008 averaged data from Passel \& Cohn.

\section{Why the rise in illegal immigration?}

The rise of illegal immigration is in some ways as much about the change in U.S. immigration policy as it is about a change in immigration patterns. Most illegal 
immigrants come from Mexico, but immigration from Mexico is not new. In the early 1900s, Mexican workers migrated to the West and Southwest to fill in for the Chinese and Japanese laborers who had essentially been banned. As more restrictive immigration policies targeting southern and eastern Europeans were passed in the early 1920s, Mexican immigration soared. During World War II and in the years following, the Bracero Program brought in over 200,000 Mexicans annually for agricultural and other work. The 1965 Immigration and Nationality Act Amendments exempted the Western Hemisphere, including Mexico, from country quotas (annual caps of 20,000 green cards) that were applied to the rest of the world.

Throughout most of the 20th century then, U.S. immigration policy accommodated immigration from Mexico in one way or another, partly in recognition of the dependence on Mexican labor in the American West. The turning point vis-à-vis preference for Mexican immigration came in 1977 with the end of this 'Western Hemisphere exemption.'

At about the same time as legal immigration from Mexico was curtailed through the imposition of country caps, many Mexicans were opting to settle permanently in the U.S. rather than continue the traditional pattern of return migration. This decrease in return migration, together with policies that curtailed opportunities for legal settlement, spurred the rise of illegal immigration. At the root of the change was a large cohort of young Mexicans coming of age at a time that the Mexican economy was waning and U.S. labor demand growing, particularly in the service and manufacturing sectors. For Mexican migrants, the change from seasonal agriculturebased work to year-round employment meant fewer trips home, longer stays, and an increased incidence of permanent settlement. Worsening economic conditions in Mexico in the 1980s continued to be a push factor. And once the Mexican migrant population was firmly in place in gateway cities in the U.S., its social networks caused families and friends to follow. ${ }^{4}$

\section{U.S. immigrants: Why do they come?}

Most U.S. immigration, whether family- or employment-based, is economically motivated in that immigrants leave their homelands in search of better economic opportunities. This stands in contrast to many other OECD nations Western European nations, for example - where non-European immigration has traditionally been reserved for refugees and asylum seekers and the government's strong social safety net has attracted such foreigners. In the U.S., while family- and employment-based immigrants share motivations, they differ in other respects. Em- 
ployment-based immigrants have higher levels of education and typically hold at least a college degree.

Consistent and strong economic growth has attracted immigrants to the U.S. This can be seen at the national level, comparing economic expansions to rises in visa applications and admissions, and also at the regional level by comparing state gross domestic product (GDP) growth to state foreign-born population growth. Chart 5 shows the fifty states in shades of grey where darker shades correspond to higher rates of foreign-born population growth. Between 1990 and 2007, the foreign-born population grew the fastest in North Carolina, Georgia, Arkansas, Tennessee, and Nevada. Over this same time period, the foreign-born population posted the slowest growth in Hawaii, Maine, Vermont, and Montana.

\section{Chart 5 \\ Growth in the Foreign-born Population (\% change) \\ 1990-2007}

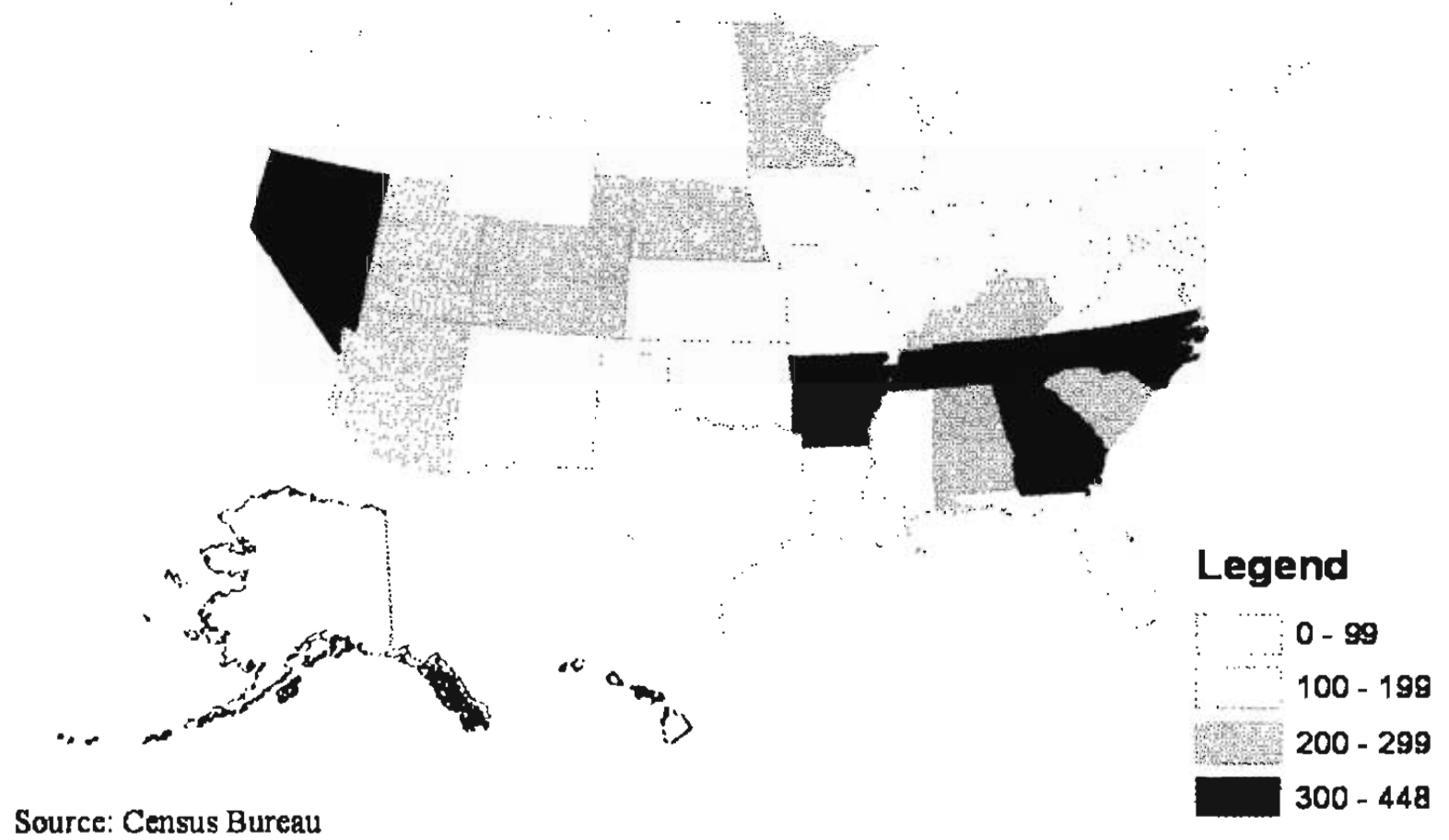

The states with the fastest pace of immigration between 1990 and 2007 also generally experienced the most rapid economic growth. Chart 6 divides the fifty states into four groups and shades them accordingly. States shaded black had aboveaverage real economic growth (GDP growth above the 61 percent median rate) and above-average foreign-born growth (foreign-born population growth above the 127 percent median rate). States shaded white had below-average growth in both cat- 
egories. Thirty-five states were shaded either black or white, implying that aboveaverage (below-average) immigration rates coincided with above-average (belowaverage) economic growth. In other words, immigrants are drawn to states where jobs are plentiful and wages are rising and tend to avoid states experiencing slower growth.

\section{Chart 6}

\section{State GDP Growth Drives Foreign-born Population Growth}

\section{0-2007}

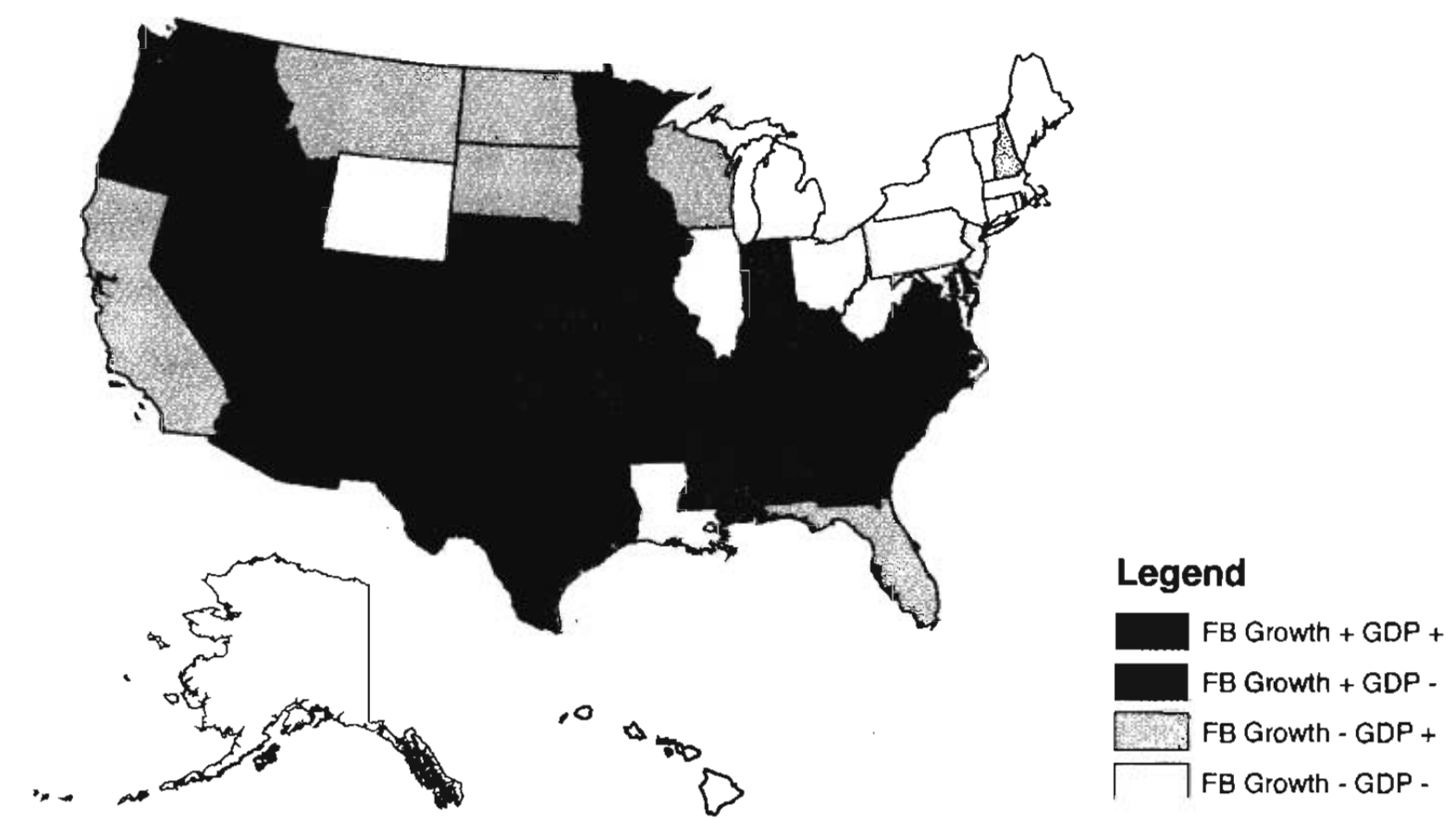

Source: Census Bureau; Bureau of Economic Analysis

What about the in-between states in Chart 6? If immigrants are drawn to growth, why did some slow-growing states have above-average immigration? These states are colored dark grey in the map and include Alabama, Indiana, Kansas, Kentucky, Missouri, Mississippi, and Oklahoma. Generally, these are states where the native-born workforce is growing very slowly or contracting, perhaps because older workers are retiring and younger, more-educated workers are leaving for fastergrowing states in the Southeast, Southwest and Mountain West. In fact, according to the Census Bureau, between 1995 and 2000 these states either experienced net population outflows (Kansas) or minimal net in-migration at a rate of 10 percent or less (Alabama, Indiana, Kentucky, Missouri, Mississippi, and Oklahoma). Despite low population growth, growing industries located in many of these states because of the favorable business climate. Instead of relying on native labor, industries such 
as meatpacking in Kansas and Oklahoma and poultry processing in Alabama, were staffed with mostly immigrant workers.

\section{Migration and the business cycle}

Immigration rates are correlated not only with long-term growth trends, as discussed above, but also with the business cycle. Migrants respond to short-term fluctuations in economic conditions in both their home and their prospective destination country. These cyclical patterns in migration are best reflected by real-time migration data, such as Border Patrol apprehensions of illegal immigrants. Because unauthorized immigrants are not encumbered or delayed by visa processing or other red tape, their migration patterns appear to clearly reflect changes in U.S. labor demand.

Chart 7 plots monthly Border Patrol apprehensions of undocumented migrants along the Southwest border from 1991 to 2007. The steep rise in apprehensions during the 1995 Mexican recession, dubbed the Tequila Crisis (represented by the first grey column), illustrates how a home-country crisis serves as a catalyst for emigration. Between December 1994 and December 1995, the Mexican peso fell 30.5 percent against the dollar in real terms and Mexico's GDP contracted by 6.7 percent. Hundreds of thousands of Mexicans headed north and apprehensions rose 121 percent.

\section{Chart 7}

\section{Real-time Migration, U.S. and Mexican Recessions}

\section{Thousands}

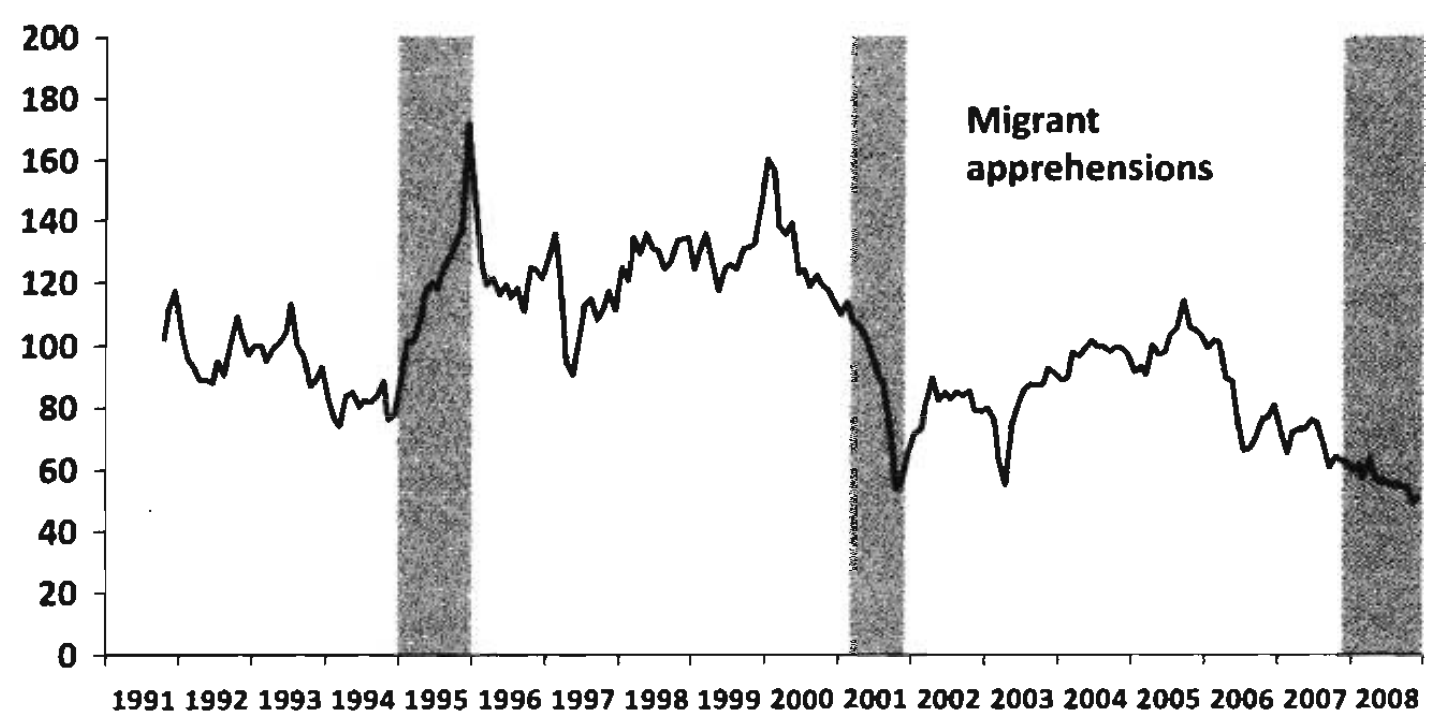

Source: Customs and Border Patrol, Department of Homeland Security; Authors' own calculations. Note: Shaded bars represent recessions. Apprehensions are seasonally adjusted. 
In late 2000 , the reverse occurred. As the U.S. economy began to slow, apprehensions began to fall. By March 2001, the U.S. had officially entered a recession (represented by the second grey column) and apprehensions had fallen 33 percent from their high in January 2000. They fell even further in the wake of the $9 / 11$ terrorist attacks.

Since 2000, apprehensions never returned to the highs of the mid- to late1990s. This is the result of both more intense border enforcement, which has raised crossing costs, and a gradual slowdown in U.S. employment growth. Payroll employment grew at an annual average rate of 2.4 percent in 1995-2000 but slowed to 0.5 percent in 2001-2008, weakening the economic incentives for immigration. Chart 8 documents the close correlation of de-trended U.S. employment (the employment level minus its long-run trend) with a 6-month lag of apprehensions, suggesting illegal immigration leads overall job growth.

\section{Chart 8}

\section{Migrant Apprehensions Track U.S. Labor Demand}

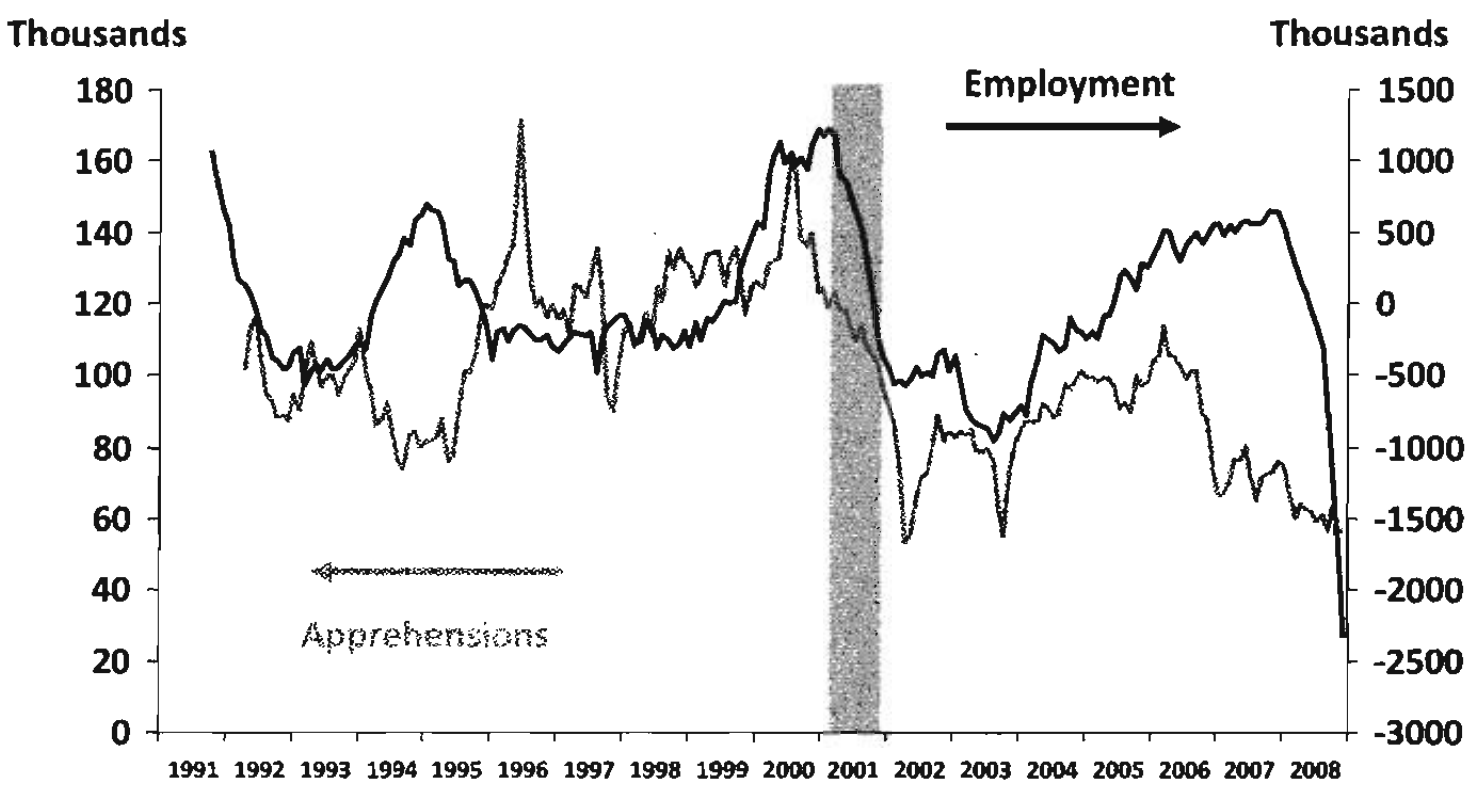

Source: Bureau of Labor Statistics, Department of Homeland Security; Authors' own calculations. Note: Shaded bars represent recessions. Employment expressed in deviations from long-run trend; Apprehensions are lagged 6 months; Apprehensions and employment are seasonally adjusted.

The current recession has caused steep declines in employment, which has put downward pressure on illegal migrant flows. Between December 2007 and December 2008, U.S. employment fell by 2.2 percent. Employment in the construction sector, a major source of employment for undocumented migrants, declined 8.9 percent. Furthermore, real U.S. GDP contracted 1 percent from the fourth quarter 
of 2007 to the fourth quarter of 2008 . This persistent slowdown has weakened migrants' employment prospects. Hence, inflows have dropped off and apprehensions are down 18.2 percent. It is likely that apprehensions will be low as long as economic growth remains weak.

\section{U.S. immigration: Effects on natives}

Immigration has a positive effect on U.S. employment and output growth. U.S. GDP is substantially higher as a result of immigration and, although the bulk of GDP gains go to the immigrants themselves in the form of labor income, the nativeborn population also benefits from the immigrant influx. Estimates suggest the gain to natives' incomes is about $\$ 30$ to 60 billion per year, which is less than 0.5 percent of GDP. The benefits of immigration accrue to native-born consumers in the form of lower relative prices of goods and services and to investors, business owners, and landowners in the form of higher return to capital and land.

Several factors detract from the natives' economic gains from immigration, however. First, the distribution of gains is problematic; gains from immigration disproportionately benefit investors, mid- and high-income consumers, and educated workers, groups which policymakers might already consider to be "doing well." Meanwhile, low-skilled native workers are often the most adversely affected as competition with immigrants depresses their wages. Second, immigration's fiscal impact may detract from its economic benefit if immigrants are low-income workers with families who use more in public services than they pay in taxes.

\section{U.S. immigration: Wage effects}

There is a large literature on the wage effects of immigration. The consensus seems to be that the biggest negative wage impacts are on prior immigrants, not natives, because prior immigrants are the most substitutable for new immigrants. The size of the wage impact also depends on the time period over which it is measured. In the short run, with a fixed capital stock, wage effects can be negative and significant. However, wage effects diminish in the medium to long run as the capital stock grows. Recent estimates based on 1990-2006 data suggest that immigration has pushed down the wages of natives by less than 1 percent in the short run, while native wages have risen slightly in the long run (Ottaviano \& Peri, 2008). This analysis also suggests that prior immigrants have sustained much higher wage losses than natives, on the order of 6 percent. Other studies find larger negative effects on native workers. In a 2003 paper, George Borjas estimates that 
immigration between 1980 and 2000 lowered average native wages by about 3 percent (Borjas, 2003).

\section{U.S. Immigration: Fiscal effects}

Another factor detracting from the economic gains of immigration is the fiscal costs of low-skilled immigration, which includes most illegal immigrants. Immigrants benefit from publicly-provided services, such as roads, police and fire protection, public schooling and emergency medical care. The bulk of these services are provided by state and local governments, which ultimately absorb much of the fiscal cost of immigration. Eligible legal immigrants who have lived in the United States for five years or more also sometimes receive welfare assistance from federal programs and joint federal-state programs such as food stamps, TANF (Temporary Assistance to Needy Families), and Medicaid. The U.S.-born children of immigrants, as U.S. citizens, are eligible for these welfare programs under the same conditions as other Americans.

Immigrant households are more likely to participate in public assistance programs than natives. In 2007, 33 percent of immigrant-headed households participated in at least one major welfare program, compared with 19 percent of native households (Camarota, 2007). Much of this difference stems from Medicaid usage as immigrants are more likely than natives to work in jobs that do not offer health insurance or where the cost of health insurance is prohibitive. It is not the case that low-income immigrant-headed households use more welfare programs because they are more likely to be out-of-work or unemployed; low-wage immigrant men have much higher employment and labor force participation rates than less educated native men despite earning lower wages.

Government outlays are offset by immigrants' contributions to public coffers through income, payroll, sales and property taxes. The net fiscal impact of immigration is the difference between immigrants' tax contributions and the value of public services they consume. In a 1997 book, the National Research Council demonstrates that the fiscal cost of immigration depends on the education level of the immigrant and the time frame over which taxes and welfare receipt are measured (Smith \& Edmonston, 1997). During their lifetimes, low-education immigrants, such as those who lack a high school degree, impose a net fiscal cost on U.S. government, while high-education immigrants, those with a college degree or higher, are a large fiscal boon. As is the case with low-wage natives, immigrants who earn relatively low wages tend to contribute less in taxes than they use in publicly provided goods and 
services. ${ }^{5}$ In the very long run, however, the contribution of descendants of immigrants make up for this initial fiscal deficit, and the net negative impact of the leastskilled immigrants gets close to zero. Of course, the faster generations assimilate, the sooner the government recoups its costs, which is one reason economic assimilation is so important.

The NRC study also notes that the average fiscal impact of immigration masks large differences across states. Due to generous welfare programs and a large low-income immigrant population, Californians likely bear the highest tax burden as a result of immigration. While Texas has a large low-income immigrant population, welfare programs are less generous and thus less costly to administer than in many other states.

While there are few reliable estimates of the fiscal cost of illegal immigration, it is generally accepted that undocumented immigrants cost less than low-skilled, legal immigrants because they are eligible for fewer public programs. Meanwhile, survey data suggests the majority of illegal immigrants work "on the books," contributing payroll and income taxes as well as property and sales taxes. In terms of public expenditures, much of the cost of illegal immigration falls on local schools and hospitals. ${ }^{6}$ As is sometimes the case for legal immigrants, children of undocumented immigrants require special attention in schools due to their lack of English proficiency. Hence, a Congressional Budget Office study suggests that the net fiscal effect of unauthorized immigration on state and local budgets is likely negative but modest (Congressional Budget Office, 2007).

As the benefits and costs of immigration are being compared, it is important to note that immigration has other important benefits that are more difficult to quantify and are not included in conventional estimates. Some of these benefits include the positive gains in innovation (particularly from skilled immigrants), on U.S. firms' competitiveness (from cheaper or more-skilled workers), on the diversity of goods and services available, on cultural diversity, and on remittances of cash to immigrants' home countries. Again, as noted in the Introduction, the largest gains from immigration accrue to immigrants themselves, and those are excluded from typical benefit-costs calculations which focus on the effect on hostcountry natives.

\section{Immigration policy: 9/11 effects and beyond}

U.S. immigration policy became more restrictive in the post-9/11 era with most of the additional security measures affecting foreigners applying for temporary 
visitor visas (tourists, businessmen) and undocumented immigrants. The effects on high-skilled workers and students have been less severe, although visas for highskilled workers are in short supply. Permanent settlement in the form of naturalization rates and green card issuances increased after $9 / 11$.

Chart 9 shows annual averages of visa issuances by category in the pre- and post-2000 periods. Tourist/business visas (shown here divided by ten) saw the largest decline of all major visa categories following $9 / 11$; they averaged 2.9 million from 2001 to 2008, substantially lower than the 1995-2000 annual average of 4.3 million. These declines in visitor visa issuances stem in part from post-9/11 security reforms, such as tougher background checks on visa applicants that resulted in much higher rejection rates as compared to the 1990s.

\section{Chart 9 \\ LPR, Work Visas Rise; Visitor Visas Fall after 9/11}

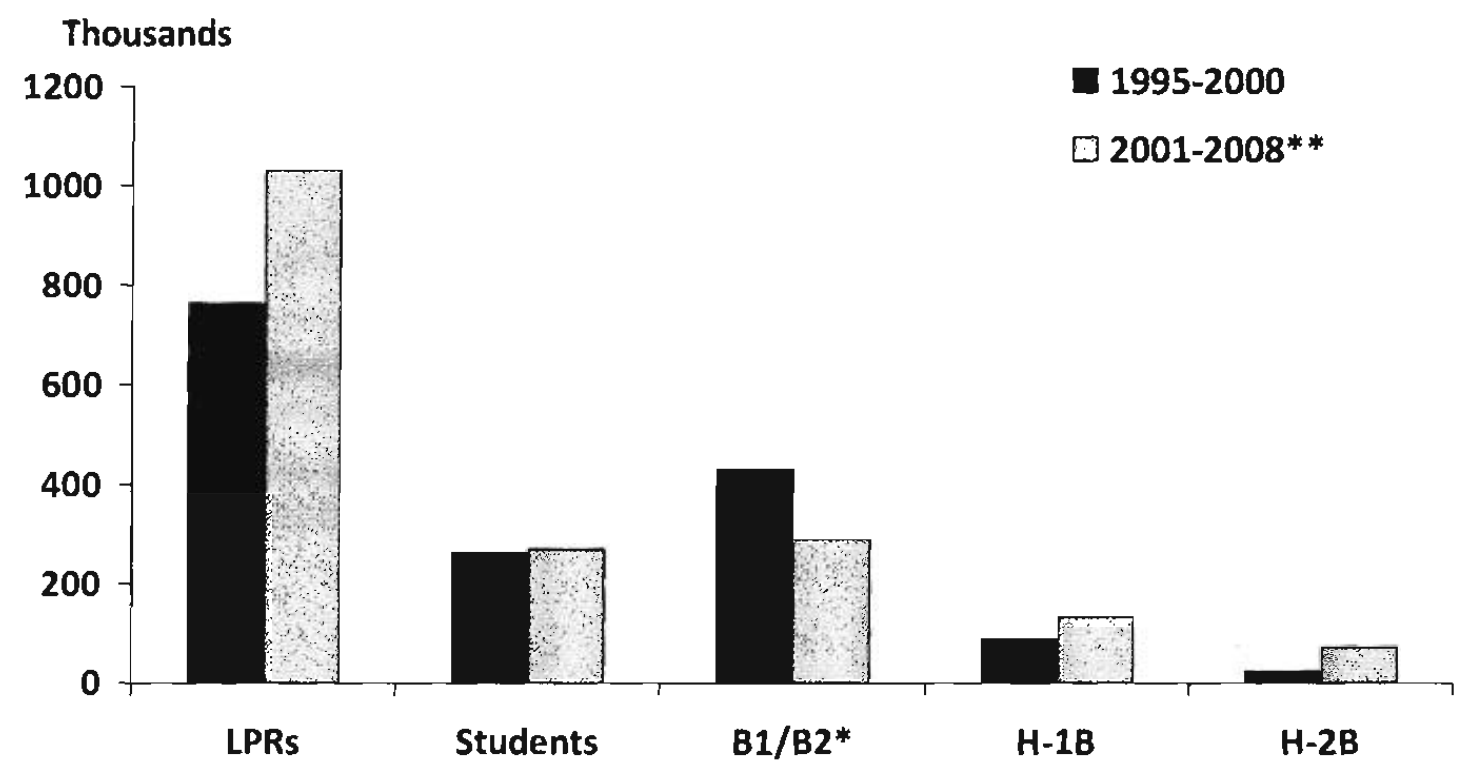

Source: Department of Homeland Security; Office of Visa Statistics; Department of State. Note: Annual average visa issuances; BI/B2 visas divided by 10; Lawful permanent resident visas are from 2001-2007.

Student visa issuances dropped off steeply following $9 / 11$ as well, but have since rebounded to even higher levels. From 2001 to 2008, student visa issuances averaged 271,000 per year, slightly more than the 1995-2000 average of 262,000.

Total visa issuances for high-skilled and low-skilled temporary workers under the H-1B and H-2B programs, respectively, increased in the 2001-2008 period. These visa programs are designed to meet specialized labor demand and require employer sponsorship. State department refusal rates are thus low for the $\mathrm{H}$ visas 
relative to other visa categories and the more stringent background checks after 9/11 had little impact. For example, in fiscal year 2002, 86.1 percent of $\mathrm{H}-1 \mathrm{~B}$ visa applications and 80.5 percent of $\mathrm{H}-2 \mathrm{~B}$ applications were approved as opposed to only 66.4 percent of student visa applications and 60.3 percent of tourist and business visa applications.

Legal permanent settlement also increased after 2001. Green card issuances rose, averaging 1.0 million per year post-2000 as compared with 762,000 in 1995 2000 , partly because so many individuals entered the U.S. with $\mathrm{H}-1 \mathrm{~B}$ visas in the 1990 s and were eligible for green cards by the 2000 s (i.e., most of the post-2000 increase does not reflect new arrivals but rather status adjusters).

\section{Current immigration policy: Binding constraints}

Most U.S. immigrants enter on the basis of family relationships, not employment. U.S. immigration policy limits employment-based immigrants by placing quotas both on employment-based green cards and on temporary nonimmigrant work visas, such as $\mathrm{H}-1 \mathrm{Bs}$ and $\mathrm{H}-2 \mathrm{Bs}$. The limits tend to be arbitrary and outdated and do not grow with the economy. For example, H-1B visa caps for the private sector were set at 65,000 as part of the Immigration Act of 1990. Since then, the economy has grown by 64 percent in real terms and employment has grown 25 percent, but the caps have not changed. ${ }^{7}$ As a result, the supply of $\mathrm{H}-1 \mathrm{~B}$ visas is too low relative to demand for workers in these categories. In fact, the government has run out of H-1B visas every year since 2004. In fiscal year 2008, the H-1B allocation of 65,000 visas for the private sector was reached in less than a week as U.S. Citizenship and Immigration Services received just over twice as many applications as it had visas to issue under the cap. The additional 20,000 H-1B visas reserved for foreign graduates of U.S. universities were also used up within a week.

Temporary nonimmigrant visas reserved for low-skilled seasonal workers, such as $\mathrm{H}-2 \mathrm{Bs}$, have also run out in each of the last 4 years. The government issues 66,000 such visas each year, and for two years allowed an exemption from the cap for returning H-2B workers. That exemption was not renewed in 2007. While in place, it allowed a little over $100,000 \mathrm{H}-2 \mathrm{~B}$ workers into the U.S., suggesting the current cap is set below demand by about 50,000 workers.

Another post-2001 development is the apparent decline in illegal immigration, particularly since 2006 . Although we cannot directly observe illegal immigration, Border Patrol apprehensions of unauthorized migrants are a good proxy for fluctuations in the flow. Total Border Patrol apprehensions in fiscal year 2007 were 
down 19.1 percent from 2006. They fell another 18.4 percent from fiscal year 2007 to 2008. The collapse of the residential construction sector that began in spring 2006 decreased demand for these migrants. At the same time, under the later years of the Bush administration, interior enforcement reached unprecedented highs, making it tougher for migrants to find and keep jobs. Chart 10 shows worksite arrests from 2002 to 2008 . While still quite low relative to the size of the U.S. labor market, the nearly 4-fold increase in total arrests from 2005 to 2008 signaled to employers that the Department of Homeland Security (DHS) had made worksite enforcement a priority.

Chart 10

Worksite Arrests Jump after 2005

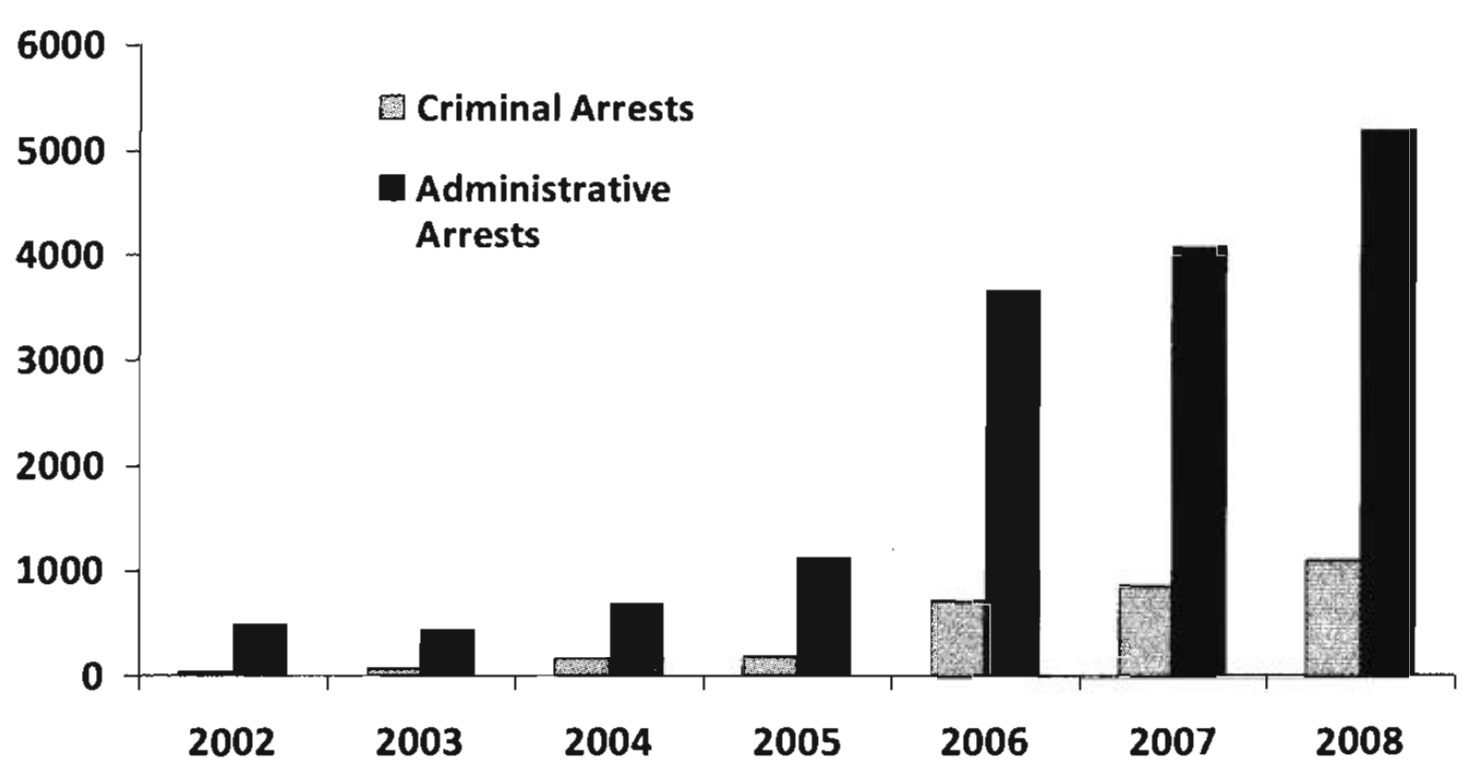

Source: Department of Homeland Security

The no-match letter program is another example of the government's desire to get tough on illegal immigrants and the employers that hire them. The DHS safe harbor guidelines, which took effect on September 14, 2007, but were placed under a court injunction shortly thereafter, require that employers fire workers with unresolved no-matches within 90 days. No-matches are cases where the employee's name does not match his Social Security number (SSN) or the SSN was never issued. Under the new guidelines, employers who fail to act in accordance with the suggested procedure would be assumed to have had 'constructive knowledge' that they were employing illegal immigrants should the employer be prosecuted. Despite the issuance of a revised rule in October 2008, the initial rule is still in 
litigation and the court injunction remains valid for the moment, stalling the implementation of the beefed-up no-match program. Regardless, the DHS's initiatives in this area send a clear message to employers that the penalty for hiring illegal immigrants is going up.

\section{Where do we go from here?}

lmmigration plays a vital role in the American economy and is likely to do so for years to come. Immigrants migrate to growing regions and industries and frequently fill jobs that natives shun. Immigrants are now the main source of growth in sectors as disparate as construction, hospitality, engineering, and health - sectors that rely heavily on low-level or high-level skills which are relatively scarce among native-born workers. Despite this, the limits on immigration are growing tighter, not looser, and the disconnect between policy and economic reality is getting bigger. The debate over illegal immigrants is paralyzing policy reform in areas that concern legal immigration; although related, the two issues have different fiscal, economic and social implications.

\section{Disclaimer}

The views expressed are those of the authors and do not necessarily reflect those of the Federal Reserve Bank of Dallas or the Federal Reserve System.

\section{Notes}

1. We use the terms 'immigrant' and 'foreign-born' interchangeably in this article to refer to all individuals residing in the U.S. who were born abroad to non-U.S. parents. Immigrants thus include legal and illegal, temporary and permanent residents.

2. For an overview of the economic effects of immigration, see Chapter 4 of the ERP (2005).

3. For up-to-date characteristics of foreign-born workers, see Bureau of Labor Statistics publication (2008).

4. For seminal work on the role of networks in Mexican migration see Douglas S. Massey, Rafael Alarcón, Jorge Durand and Humberto Gonzalez (1987).

5. For annual estimates of the net fiscal costs of low-skilled immigrant households, see Robert Rector and Christine Kim (2007). 
6. A 2006 Texas study by the state's comptroller indicates that local governments bear the majority of the costs related to illegal immigration and estimates a net fiscal benefit at the state level. See Strayhorn (2006).

7. Since 2005, 20,000 visas for foreign students who graduate from U.S. universities with advanced degrees were made exempt from the cap.

\section{References}

Borjas, G. (2003). The labor demand curve is downward sloping: Reexamining the impact of immigration on the labor market. Quarterly Journal of Economics, $118,1335-1374$.

Bureau of Labor Statistics (2008). Foreign-born workers: Labor force characteristics in 2008. Retrieved March 26, 2009, from www.bls.gov/news.release/pdf/forbrn. pdf.

Camarota, S. (2007). Immigrants in the United States, 2007: A profile of America's foreign-born population. Center for Immigration Studies. Retrieved November, 2007, from www.cis.org/immigrants_profile_2007.

Congressional Budget Office (2007). The impact of unauthorized immigrants on the budgets of state and local governments. Retrieved December, 2007, from www. cbo.gov/ftpdocs/87xx/doc8711/12-6-Immigration.pdf.

Council of Economic Advisers (2005). Economic report of the President. Washington, DC: Government Printing Office.

Freeman, R. B. (2005). Does globalization of the scientific/ engineering workforce threaten U.S. economic leadership? NBER Working Paper 11457 (July).

Massey, D. S., Alarcon, R., Durand, J., \& Gonzalez, H. (1987). Return to Aztlan: The social process of international migration from Western Mexico. Berkeley and Los Angeles, California: University of California Press.

Ottaviano, G., \& Peri, G. (2008). Immigration and national wages: Clarifying the theory and empirics. NBER Working Paper 14188 (July).

Ottaviano, G., \& Peri, G. (2006). Rethinking the effects of immigration on wages. NBER Working Paper 12497 (August).

Passel, J., \& Cohn, D. (2008). Trends in unauthorized immigration. Retrieved October 2, 2008, from www.pewhispanic.org/reports/report.php?ReportlD=94.

Passel, J., \& Suro, R. (2005). Rise, peak and decline: Trends in U.S. immigration 1992-2004. Retrieved September 27, 2005, from pewhispanic.org/files/ reports/53.pdf. 
Rector, R., \& Kim, C. (2007). The fiscal cost of low-skill immigrants to the U.S. taxpayer. The Heritage Foundation Leadership for America, Special Report 14.

Smith, J. P., \& Edmonston, B. (1997). The new Americans: Economic, demographic, and fiscal effects of immigration. Washington, DC: National Academy Press.

Social Security Administration (2007). Nation's first baby boomer files for Social Security Retirement Benefits - Online! Retrieved October 15, 2007, from www. ssa.gov/pressoffice/pr/babyboomerfiles-pr.htm.

Strayhorn, C. K. (2006). Undocumented immigrants in Texas: A financial analysis of the impact to the state budget and economy. Texas Comptroller of Public Accounts, Special Report. Retrieved December, 2006, from www.window.state. tx.us/specialrpt/undocumented/.

\section{Biographical Sketch of Authors}

Pia Orrenius is Senior Economist and Policy Advisor at the Federal Reserve Bank of Dallas and Adjunct Professor at the Hankamer School of Business, Baylor University. Her research focuses on the labor market impacts of immigration, illegal immigration, and U.S. immigration policy, and her work has been published in the Journal of Development Economics, Labour Economics, Industrial and Labor Relations Review, Demography, among others. Dr. Orrenius is a Research Fellow at The Tower Center for Political Studies at Southern Methodist University and at the Institute for the Study of Labor in Bonn, as well as a member of the Council on Foreign Relations. Dr. Orrenius was senior economist on the Council of Economic Advisers in the Executive Office of the President, Washington D.C. in 2004-2005. She received her Ph.D. in economics from the University of California at Los Angeles and B.A. degrees in economics and Spanish from the University of Illinois at Urbana-Champaign.

Mike Nicholson is a Research Analyst at the Federal Reserve Bank of Dallas. $\mathrm{He}$ is a frequent contributor to Southwest Economy, a quarterly Dallas Fed publication. Nicholson graduated from the University of Pennsylvania in 2005 with majors in economics and international relations. He spent the 2005-2006 academic year at Koç University in Istanbul, Turkey, where he was a Fulbright Scholar. 
